\title{
Which matters most for the formation of intra-annual density fluctuations in Pinus pinaster: age or size?
}

\author{
Filipe Campelo $\cdot$ Joana Vieira $\cdot$ Giovanna Battipaglia $\cdot$ \\ Martin de Luis · Cristina Nabais · Helena Freitas • \\ Paolo Cherubini
}

Received: 17 February 2014/Revised: 2 October 2014/ Accepted: 8 October 2014/Published online: 31 October 2014

(c) Springer-Verlag Berlin Heidelberg 2014

\begin{abstract}
Key message A new method is proposed to standardize chronologies of intra-annual density fluctuations to improve their intra-annual climatic signal.

Abstract In the Mediterranean area, intra-annual density fluctuations (IADFs) are triggered by short-term climatic variations during the growing season. It is known that the formation of these anatomical structures is dependent on age and size, which can represent a problem during the extraction of the environmental signal from IADF chronologies. We present a new method using a two-step approach to remove the effect of tree-ring width from IADF chronologies. The climatic signal of IADF
\end{abstract}

Communicated by S. W. Leavitt.

F. Campelo $(\bowtie) \cdot$ J. Vieira $\cdot$ C. Nabais $\cdot$ H. Freitas Department of Life Sciences, CFE-Centre for Functional Ecology, University of Coimbra, Calçada Martim de Freitas, 3000-456 Coimbra, Portugal

e-mail: fcampelo@ci.uc.pt

G. Battipaglia

Department of Environmental, Biological and Pharmaceutical Sciences and Technologies, Second University of Naples, Caserta 81100, Italy

G. Battipaglia

Centre for Bio-Archaeology and Ecology, Institut de Botanique, Ecole Pratique des Hautes Etudes (PALECO EPHE), University of Montpellier 2, Montpellier 34090, France

M. de Luis

Department of Geography and Regional Planning, University of Zaragoza, C/Pedro Cerbuna 12, 50009 Saragossa, Spain

P. Cherubini

WSL Swiss Federal Institute for Forest, Snow and Landscape Research, 8903 Birmensdorf, Switzerland chronologies obtained by the proposed method was compared with previous methods, using 160 Pinus pinaster tree cores from an even-aged stand on the west coast of Portugal. Our results show that the climatic signal of IADF chronologies was strongly affected by the standardization method used, and that it could be improved by removing the effect of the predisposing factors (cambial age and treering width) on IADF formation. Moreover, additional climatic information (previous winter precipitation) was only revealed when the effect of tree-ring width was removed from IADF series. Finally, we propose that this new method should be tested for other species and across larger geographical areas to confirm its capacity to remove noise from IADF chronologies and to improve their intra-annual climatic signal.

Keywords Ecological wood anatomy - Intra-annual density fluctuation - Maritime pine $\cdot$ Mediterranean climate $\cdot$ Standardization

\section{Introduction}

The formation of anatomically distinct growth rings in trees results from the interaction between external and internal factors. This interaction changes as trees get older and bigger, resulting in a general decline of tree-ring width, the so-called age trend commonly found in ring-width chronologies (e.g. Esper et al. 2008). The effect of age on the climatic signal of tree rings has been widely studied, but with contradictory findings (Carrer and Urbinati 2004; Dorado Liñán et al. 2012). Some studies found a stronger climatic signal in older trees (Carrer and Urbinati 2004), others in younger (Vieira et al. 2009) and others did not observe any difference between age classes (Esper et al. 
2008; Dorado Liñán et al. 2012). The contrasting findings regarding the age-dependent response of tree-ring width to climate could be caused by the effect of tree size. As trees get older they also get larger, and although rings tend to be narrower, a higher volume of wood is produced each year (Mencuccini et al. 1997), affecting the water supply for transpiration which in turn can change the response of tree growth to climate. In an attempt to isolate the effect of size from age, De Luis et al. (2009) compared the climatic signal of two-stem diameter classes of Aleppo pine (Pinus halepensis Mill.) and stone pine (Pinus pinea L.) in evenaged stands, finding that smaller-diameter trees show higher sensitivity to climate. Different results were obtained by Campelo et al. (2013), who found a similar climatic signal for two size classes of maritime pine (Pinus pinaster Ait.) in an even-aged stand. Such differences might be explained by site conditions and species-specific water use (Kunert et al. 2010).

Other anatomical features observed in tree rings have also been found to be related to the age and size of trees. Such variables include vessel density and lumen area in angiosperms (Battipaglia et al. 2010; De Micco et al. 2012; Battipaglia et al. 2013) and the frequency of intra-annual density fluctuation (IADFs) in conifers (Vieira et al. 2010; De Luis et al. 2011a; Campelo et al. 2013; De Micco et al. 2014). IADFs are anatomical structures formed in response to short-term fluctuations in weather conditions during the growing season and are characterized by latewood-like cells within earlywood or earlywood-like cells in the latewood (Cherubini et al. 2003). Intra-annual density fluctuations are commonly observed in pine species growing in the Mediterranean area, such as $P$. pinea (Campelo et al. 2007), P. pinaster (De Micco et al. 2007; Vieira et al. 2009; Rozas et al. 2011; Campelo et al. 2013) and P. halepensis (De Luis et al. 2007, 2011a; Olivar et al. 2012; Novak et al. 2013b). The effect of age on IADF formation has been studied in conifers from different locations and environments, and it has been concluded that IADFs were more frequently expressed in younger trees (Copenheaver et al. 2006; Vieira et al. 2009; Battipaglia et al. 2010; Novak et al. 2013b). However, a relation between IADF frequency and tree-ring width has also been observed, with wider rings exhibiting a higher frequency of IADFs (Rigling et al. 2001; Novak et al. 2013b; Campelo et al. 2013), suggesting that trees showing higher growth rates are more prone to form IADFs. Also, IADFs rarely occur in extremely narrow rings or during periods of suppressed growth (Bräuning 1999; Rigling et al. 2001; Copenheaver et al. 2006). The effect of age and tree-ring width on IADF formation is not well understood because the formation of these anatomical structures is associated with multiple factors that can interact with each other. These factors can be divided in two types: predisposing and triggering factors (Marchand and Filion 2012). Here, we propose that cambial age, treering width, soil water-holding capacity and growing season length are among the predisposing factors for IADF formation, whereas the triggering factors are short-term fluctuations in weather conditions during the growing season.

When building a ring-width chronology, tree-ring width series are first standardized to remove biological trends related to tree age/size. However, chronologies of anatomical features obtained from binary data (presence/ absence of IADFs) are usually not standardized, despite evidence that indicates the frequency of such features are age/size dependent (Vieira et al. 2009; Campelo et al. 2013). Novak et al. (2013b) suggested the use of a 3-parameter Weibull function to remove the effect of age from IADF chronologies. Indeed, tree-ring width and the frequency of IADFs tend to decline with tree age, meaning that the decreasing frequency of IADFs as trees get older can also be related to a decrease in tree-ring width. Furthermore, Campelo et al. (2013) found that in an even-aged stand larger trees (with wider rings) showed almost $15 \%$ more IADFs than smaller trees (with narrow rings). Therefore, one can consider that removing the ring-width effect would simultaneously reduce the effect of size and/ or age on IADF formation. On the contrary, removing only the effect of cambial age will not remove the effect of treegrowth vigor on IADF formation, as happens during periods of tree-growth suppression and release (Bräuning 1999; Copenheaver et al. 2006). With the aim of isolating the triggering factor of IADF formation and maximizing the climatic signal of these anatomical structures, we compared IADF frequency chronologies using three different methods. The first method, proposed by Osborn et al. (1997), stabilizes the relative frequency of IADFs by taking into account the changing sample depth over time. The second method is a one-step detrending method that removes the effect of cambial age from IADF chronologies using a Weibull function (Novak et al. 2013b). As an alternative approach a new standardization method is here proposed to remove the effect of cambial age and tree-ring width on IADF formation, using a Chapman function. We hypothesized that IADF formation is age and ring-width dependent and that removing the effect of tree-ring width from IADF chronologies improves their climatic signal.

\section{Methods}

Tree species and study area

Pinus pinaster has its natural distribution in the western Mediterranean Basin and is one of the most important tree species in Portugal (Pereira 2002). It is a fast growing species with pronounced drought- and salt-resistance and, 
therefore, has been cultivated to stabilize sand dunes. Our study area is in an even-aged managed forest of $P$. pinaster in Perímetro Florestal Dunas de Cantanhede, located on the west coast of Portugal $\left(40^{\circ} 21^{\prime} 35^{\prime \prime} \mathrm{N}, 8^{\circ} 49^{\prime} 10^{\prime \prime} \mathrm{W}\right)$. The climate is typically Mediterranean with oceanic influence, with a marked summer drought. Monthly climate data (mean air temperature and precipitation) were obtained from the web site of the Royal Netherlands Meteorological Institute (http://www.climexp.knmi.nl/). Over the last three decades (1980-2009), the mean annual temperature was $16.2{ }^{\circ} \mathrm{C}$ and the mean annual precipitation $953 \mathrm{~mm}$. The average winter (December-February) and summer (JuneAugust) temperatures were 11.2 and $21.3^{\circ} \mathrm{C}$, respectively. Most of the precipitation occurs from late autumn to early spring, with January having the highest monthly average precipitation $(114 \mathrm{~mm})$. Soils are acidic with sandy texture and low water-holding capacity.

\section{Tree-ring data}

To achieve a representative sampling of the site, namely its size structure, sixty trees were sampled, and divided into two-stem diameter classes: small $(<27 \mathrm{~cm})$ and large (>35 cm) (Campelo et al. 2013). In 2009 two cores were extracted in the north-south direction, at breast height, from dominant and co-dominant trees. The increment cores were sanded with progressively finer grades of sandpaper to produce a flat, polished surface on which tree-ring boundaries and individual tracheids were clearly visible under magnification (Orvis and Grissino-Mayer 2002). Tree rings were crossdated and ring width was measured to the nearest $0.01 \mathrm{~mm}$ using a linear table, LINTAB (Frank Rinn S.A, Heidelberg, Germany) and the program TSAPWin (Rinn 2003). When samples at the coring height showed the pith, the number of annual rings determined the cambial age. When both cores from a given tree did not contain the pith, the curvature of the innermost rings was used to estimate pith offset according to the method suggested by Liu (1986). Tree-ring width (TRW) series were aligned by cambial age and a mean curve was calculated from these data, using the packages dplR (Bunn 2008) and detrendeR (Campelo et al. 2012) from the $\mathrm{R}$ freeware program (http://cran.r-project.org).

\section{Intra-annual density fluctuations}

Cores were examined for detecting IADFs using a stereomicroscope (magnification up to $25 \times$ ). These anatomical structures are easily detected by their gradual transition in cell size and wall thickness at outer borders, in contrast to the abrupt transition between latewood and earlywood of adjacent rings. In the present study, only IADFs located on latewood were considered, which are characterized by the presence of earlywood-like cells within true latewood or between latewood and the earlywood of the next ring. Indeed, several studies in Pinus species in the Iberian Peninsula have found that IADFs are more frequent in latewood than in earlywood (Campelo et al. 2007; Vieira et al. 2009; Rozas et al. 2011; Novak et al. 2013a). The relative frequency of IADFs per year $(F)$ was calculated as the ratio:

$F=\frac{N}{n}$

where $N$ is the number of cores showing the same type of IADF in a given year, and $n$ is the number of cores in that year. For each year, the average ring width was calculated for rings with and without IADFs. In the same way, for each year the average of the relative frequency of IADFs was calculated for both groups (with and without IADFs). For the period 1960-2008 ( $n \geq 40$ cores), differences in width between rings with and without IADFs were investigated using a paired $t$ test; in this analysis only years with at least 5 cores showing IADFs were considered.

Development of IADF chronologies using different approaches

To correct the bias introduced by changing sample depth over time on relative frequency of IADFs, a stabilized IADF frequency, $f$, can be calculated as:

$f=F \times \sqrt{n}$

where $F$ is the relative frequency of IADFs (Osborn et al. 1997). Finally, a stabilized chronology of IADF frequency $\left(\mathrm{IADF}_{f}\right)$ is calculated by averaging all $f$ series of IADFs. This approach has been applied in most of the studies evaluating the climatic signal of IADFs (Rigling et al. 2001; Campelo et al. 2007; De Luis et al. 2011b).

Recently, Novak et al. (2013b) proposed a one-step detrending method to remove the effect of cambial age on IADF formation using a 3-parameter Weibull function:

$\operatorname{IADF}_{(\text {Age })}=a \times \operatorname{Age}^{2} \times \mathrm{e}^{-b \times \operatorname{Age}^{c}}$

where $\mathrm{IADF}_{(\text {Age })}$ is the observed relative frequency of rings with IADF, Age is the cambial age and $a, b$ and $c$ are fitting parameters. Cambial age corresponds to the number of rings between the pith and the cambium, which is highly dependent of the vertical position within the stem. We used cambial age instead of tree age, since it is known that the occurrence of IADFs varies with the vertical position within the stem, which makes cambial age a predisposing factor for IADF formation (Marchand and Filion 2012).

Here, we present a new method using a two-step approach to remove the effect of TRW on the occurrence of IADFs to improve the climatic signal of IADF 
chronologies. In the proposed method, rings from all samples are divided into 20 ring-width classes and mean tree-ring width and IADF relative frequency are calculated for each one. To this end a function was written in $\mathrm{R}$ to divide rings into ring-width classes. This function sorts all rings according to their width and then divides those rings into 20 groups, each one with a similar number of rings; the first group (1-class) has the narrowest rings, whereas the last group (20-class) contains the widest rings. The mean relative frequency of IADFs and the mean ring width were calculated for each group. A 3-parameter Chapman function was fitted to these data to define the relationship between tree-ring width and IADF frequency:

$\overline{\mathrm{IADF}}_{\text {class }}=a \times\left(1-\mathrm{e}^{-b \times \overline{\mathrm{TRW}}_{\text {class }}}\right)^{c}$

where $\overline{\mathrm{IADF}}_{\text {class }}$ is the mean relative frequency of IADFs and $\overline{\mathrm{TRW}_{\text {class }}}$ is the mean ring width for each ring-width class and $a, b$, and $c$ are the fitting parameters. Thereafter, for each core, indices are calculated as the difference between the occurrence of IADFs ( 0 , absence; 1 , presence) and the predicted relative frequency of IADFs using the Chapman function. Finally, the obtained IADF frequency indices are averaged into a chronology of IADFs and a cubic smoothing spline with $50 \%$ frequency cutoff of 20 years is subtracted from this chronology to produce an IADF chronology $\left(\mathrm{IADF}_{t r w}\right)$, which is ring width and age independent. We used the spline to remove some "trends" from the IADF chronology, since these "trends" are considered as noise caused by aging-especially for trees younger than 27 years - and by changes in tree competition (tree-growth release and suppression).

\section{Climatic signal of IADF chronologies}

The three types of IADF chronologies $\left(\mathrm{IADF}_{f}, \mathrm{IADF}_{\text {age }}\right.$ and $\mathrm{IADF}_{t r w}$ ) were used to investigate the climatic signal by means of simple correlation coefficients $(r)$ between monthly climate variables (descriptors) and IADF chronologies, for the period 1960-2008. Before performing the analysis, trends in descriptors were removed by application of linear functions. According to previous studies (Rozas et al. 2011; Campelo et al. 2013; Vieira et al. 2014), the growing season of $P$. pinaster in the Mediterranean area is from March to December. For this reason, we used monthly climate variables from March to current December. Additionally, monthly climatic variables between October of the previous year and the current February were grouped into a seasonal variable to illustrate conditions before the growing season.

A significant pairwise correlation does not necessarily mean an independent effect of the specific descriptor, since several descriptors can be correlated with each other, as usually happens for climatic variables. Because of this, significant descriptors obtained by simple correlations were re-analyzed using partial correlations, which measure the relationship between a descriptor and the IADF chronology while controlling for one or more variables, to quantify the independent contribution of each variable. The difference in partial correlations between descriptors obtained using both types of IADF chronologies $\left(\mathrm{IADF}_{a g e}\right.$ and $\mathrm{IADF}_{t r w}$ ) was evaluated statistically using a robust bootstrapping method, for the period 1960-2008. Partial correlations between IADF chronologies $\left(\mathrm{IADF}_{\text {age }}\right.$ and $\left.\mathrm{IADF}_{t r w}\right)$ and climatic variables were repeatedly calculated by randomly re-sampling cores with replacement from the original sample. The bootstrap mean differences between partial correlations were considered statistically significant at the 0.01 level when both $99 \%$ confidence intervals of the distribution were either lower or higher than zero. We conducted 10,000 bootstrap resamples in the analysis.

\section{Results}

At breast height, the cambial age of the last ring (year 2008) ranged between 41 and 54, even though trees were from an even-aged stand (Campelo et al. 2013). Cambial age was used instead of tree age to determine the effect of cambial age on IADF formation independently from that of calendar year. Additionally, for a given cambial age the IADF frequency was not determined by climatic conditions (triggering factor), but only by age and tree-ring width (predisposing factors). For tree rings younger than 15 years, an opposite trend was detected for TRW and IADFs frequency, with a higher frequency of IADFs being observed in smaller rings, whereas for older rings an identical trend was observed (Fig. 1).

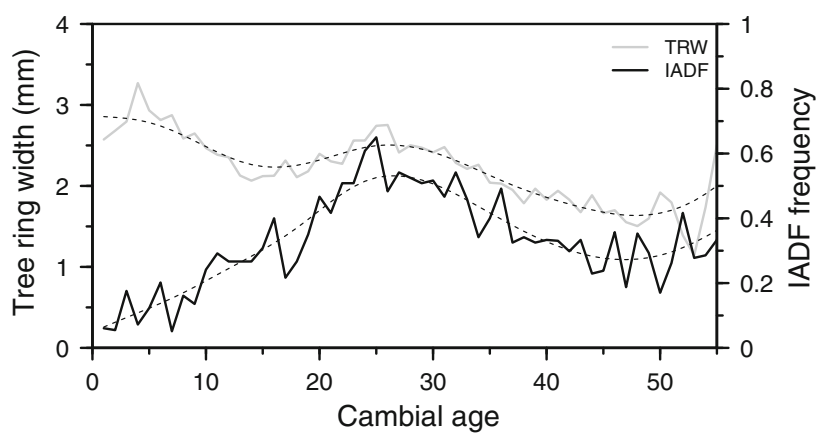

Fig. 1 Variation of tree-ring width (TRW) and intra-annual density fluctuation (IADF) frequency over cambial age. A spline with $50 \%$ frequency cutoff of 20 years length is added to each variable (dashed line) 


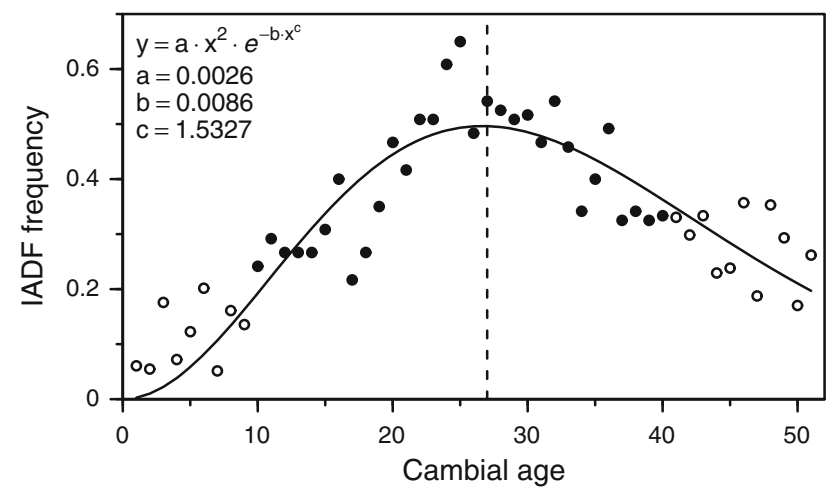

Fig. 2 Variation of intra-annual density fluctuation (IADF) frequency as a function of cambial age. Only years with more than 40 cores $(n>40)$ were considered to fit the 3-parameter Weibull function (solid line). Filled circles represent years using all cores $(n=120)$, whereas open circles represent years with fewer cores $(40<n<120)$

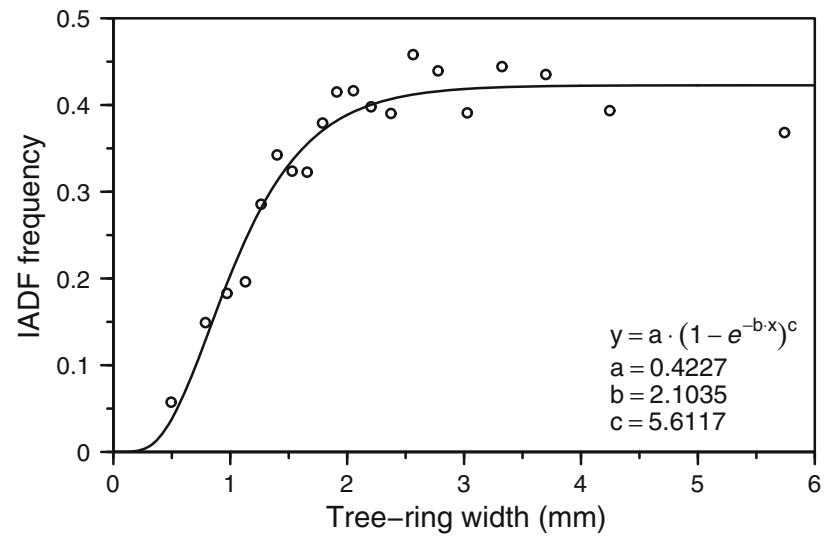

Fig. 3 Variation of intra-annual density fluctuation (IADF) frequency as a function of tree-ring width. Each point represents the average ring-width and the relative IADF frequency for the corresponding ring-width class. The solid line represents the 3-parameter Chapman function

The IADF frequency estimated by the 3-parameter Weibull equation increased with cambial age until the age of 27 and then decreased (Fig. 2). The frequency of IADFs changed with TRW (Fig. 3) and the relative frequency of IADFs could be successfully estimated using a 3-parameter Chapman function. According to the Chapman function, the IADF frequency increased with tree-ring width up to a $2 \mathrm{~mm}$ width and afterwards reached a plateau (Fig. 3).

The IADF age and $\mathrm{IADF}_{t r w}$ chronologies showed a similar pattern and were strongly correlated $(r=0.83, n=56$, $p<0.001$, Fig. 4), indicating similar information in both chronologies. For the period 1960-2008, tree rings with IADFs were on average 1.3 times wider than rings without IADFs $(t=7.15, d f=42, p<0.001)$.

The correlations between climate and IADF chronologies revealed that the third method $\left(\mathrm{IADF}_{t r w}\right)$ produced

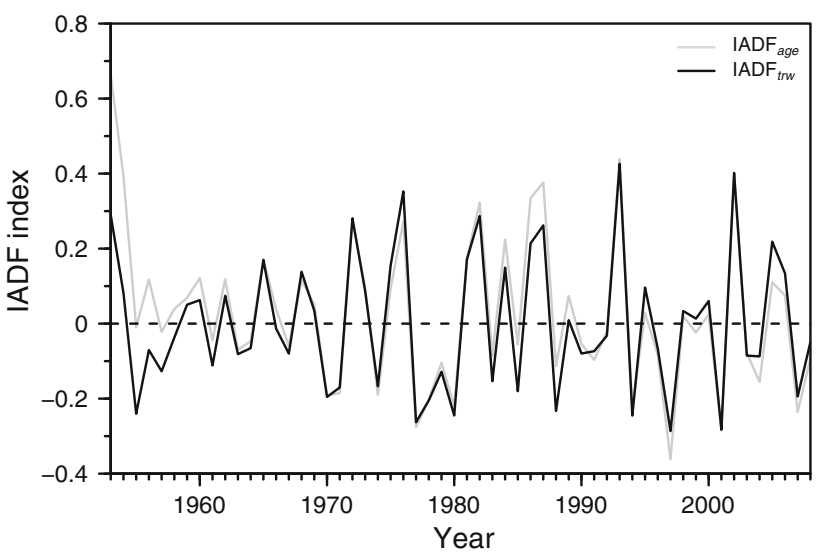

Fig. 4 Frequency of intra-annual density fluctuations with the age effect $\left(\mathrm{IADF}_{\text {age }}\right)$ and tree-ring width effect $\left(\mathrm{IADF}_{t r w}\right)$ removed in relation to calendar year

better results than the other methods $\left(\mathrm{IADF}_{f}\right.$ and $\left.\mathrm{IADF}_{\text {age }}\right)$ (Fig. 5). The significant correlation obtained between $\mathrm{IADF}_{f}$ and December temperature was not observed for either $\mathrm{IADF}_{\text {age }}$ or $\mathrm{IADF}_{t r w}$. The highest correlation observed was between $\mathrm{IADF}_{t r w}$ and September precipitation $(r=0.6)$. A significant negative correlation was observed between $\mathrm{IADF}_{t r w}$ and September temperature, whereas no significant correlation was attained for $\mathrm{IADF}_{\text {age }}$. In September, temperature and precipitation were strongly negatively correlated $(r=-0.47 ; n=49$; $p<0.001$ ), suggesting that partial correlations should be used to identify the contribution of each descriptor. Partial correlations for descriptors showing significant simple correlations with $\mathrm{IADF}_{a g e}$ or $\mathrm{IADF}_{\text {trw }}$ are shown in Table 1. For September precipitation, partial correlations were significant for both types of IADF chronologies $\left(\mathrm{IADF}_{\text {age }}\right.$ or $\left.\mathrm{IADF}_{t r w}\right)$, whereas precipitation during October-February was only significantly correlated with $\mathrm{IADF}_{\text {trw }}$ (Table 1). Additionally, the partial correlations revealed no significant relationships for precipitation in June and temperature in September (Table 1).

For descriptors with significant partial correlations with IADF chronologies (precipitation October-February and September), the mean difference between partial correlations obtained using both standardized methods and their $99 \%$ confidence intervals resulting from 10,000 bootstrap re-samples are depicted in Table 2 . The partial correlations between significant descriptors and $\mathrm{IADF}_{\text {age }}$ and $\mathrm{IADF}_{t r w}$ were significantly different. The highest partial correlation obtained from bootstrap iterations was between $\mathrm{IADF}_{t r w}$ and precipitation in September $(r=0.65)$. Most of the iterations $(83.3 \%)$ showed significant partial correlation between precipitation October-February and $\mathrm{IADF}_{t r w}$, whereas only $9.8 \%$ of the iterations showed significant partial correlations for $\mathrm{IADF}_{\text {age }}$. For both standardized IADF chronologies (IADF ${ }_{a g e}$ and $\mathrm{IADF}_{t r w}$ ), all the 


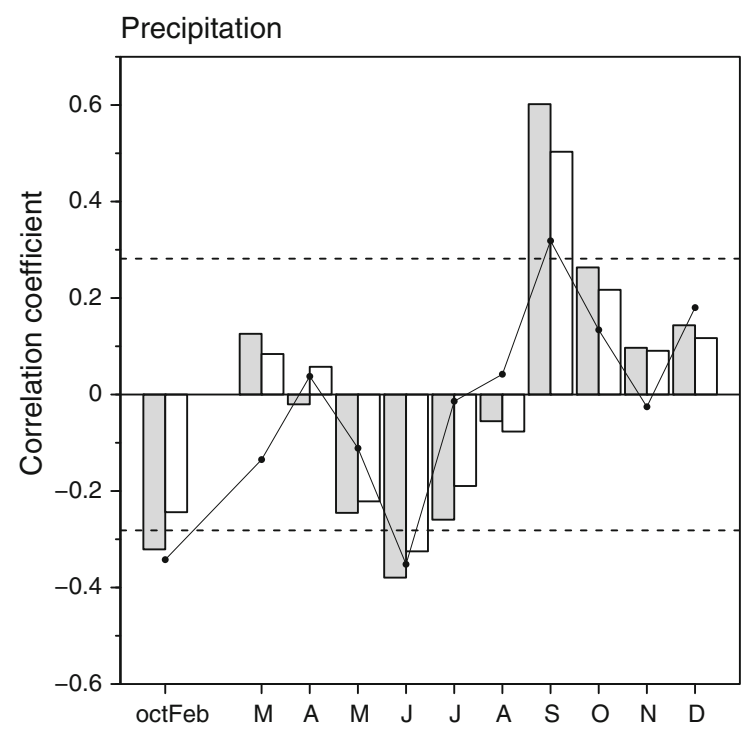

Fig. 5 Correlation coefficients between monthly precipitation (left) and temperature (right) data from January to December of the current year, for the period of 1960-2008 and the stabilized frequency of intra-annual density fluctuations ( $\mathrm{IADF}_{f}$; black dots), the frequency of intra-annual density fluctuations with the age effect removed

Table 1 Simple and partial correlations between descriptors (with significant simple correlations) and both types of chronologies: the frequency of intra-annual density fluctuations without the age effect $\left(\mathrm{IADF}_{\text {age }}\right)$ and the frequency of intra-annual density fluctuations with the tree-ring width effect removed $\left(\mathrm{IADF}_{t r w}\right)$

\begin{tabular}{|c|c|c|c|c|}
\hline \multirow[t]{2}{*}{ Descriptors } & \multicolumn{2}{|c|}{ Simple correlation } & \multicolumn{2}{|c|}{ Partial correlation } \\
\hline & $\mathrm{IADF}_{\text {age }}$ & $\mathrm{IADF}_{t r w}$ & $\mathrm{IADF}_{\text {age }}$ & $\mathrm{IADF}_{t r w}$ \\
\hline \multicolumn{5}{|l|}{ Precipitation } \\
\hline October-February & -0.24 & $-0.32 *$ & -0.20 & $-0.30 *$ \\
\hline June & $-0.33^{*}$ & $-0.38 * *$ & -0.14 & -0.18 \\
\hline September & $\mathbf{0 . 5 0} * * *$ & $0.60 * * *$ & $0.42 *$ & $\mathbf{0 . 5 3} * * *$ \\
\hline \multicolumn{5}{|l|}{ Temperature } \\
\hline September & -0.23 & -0.35 & -0.12 & -0.13 \\
\hline
\end{tabular}

Bold values are significant correlations and asterisks indicate levels of significance: $* p<0.05 ; * * p<0.01 ; * * * p<0.001$

iterations showed significant partial correlations with September precipitation.

\section{Discussion}

In this paper we propose a new method to remove the treering width effect on the formation of IADFs to enhance the climatic signal of IADF chronologies. The climatic signal obtained using this method was compared with the one proposed by Novak et al. (2013b), in which a 3-parameter Weibull function was used to remove the effect of cambial age on IADF formation. The results obtained showed that

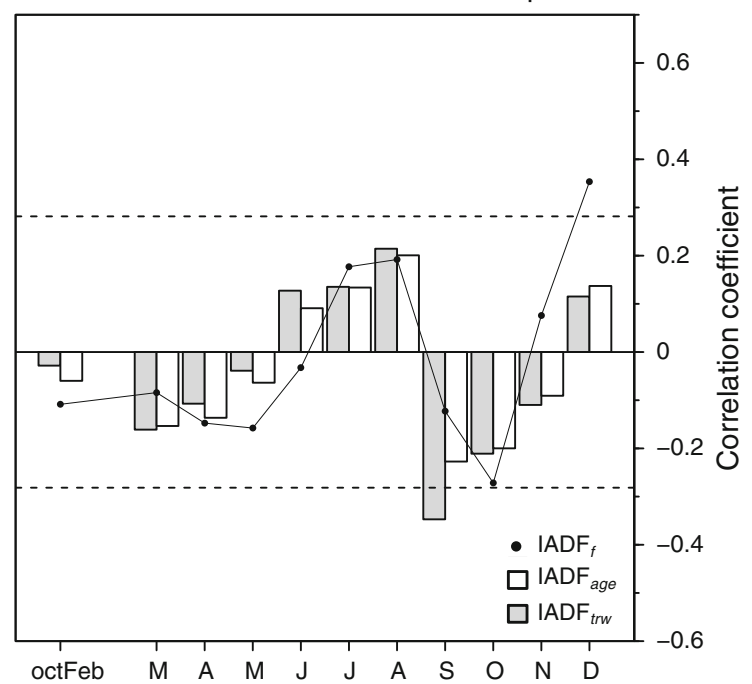

$\left(\mathrm{IADF}_{\text {age }}\right.$; open bars) and the frequency of intra-annual density fluctuations with the tree-ring width effect removed (IADF $t r w$; shaded bars). Horizontal lines indicate the significance levels for $p<0.05$ $(n=49)$

the climatic signal of IADF chronologies is strongly affected by the standardization method used to remove the effect of predisposing factors. The new method efficiently removes the effect of both predisposing factors (tree-ring width and cambial age) on IADF formation, improving the climatic signal of IADF chronologies. Finally, using this method it is possible to develop a standardized IADF chronology without knowing cambial age, preventing potential errors in estimating cambial age when the pith is not present.

In our study, a high frequency of IADFs was found with more than $34 \%$ of the rings showing IADFs located in latewood. Similar findings were reported by Rozas et al. (2011) who found IADFs in more than $30 \%$ of the rings in most of the studied sites and a maximum frequency of IADFs higher than $80 \%$. Although IADFs have been considered as special anatomical features resulting from variations in the cambial activity (De Luis et al. 2007; Battipaglia et al. 2013), in $P$. pinaster IADFs are more the rule than the exception (Rozas et al. 2011). In fact, a high occurrence of IADFs in $P$. pinaster indicates a great capacity to adjust its cambial activity to the current environmental conditions. Previous studies have found that this species can resume cambial activity after the summer drought, whenever environmental conditions are favorable (Vieira et al. 2009; Campelo et al. 2013). Identical findings were found for other Mediterranean conifers, such as $P$. halepensis (De Luis et al. 2007), $P$. pinea (Campelo et al. 2007) and Juniperus thurifera L. (Camarero et al. 2010). 
Table 2 Differences between partial correlations between precipitation $(\mathrm{P})$ and both types of chronologies: the frequency of intra-annual density fluctuations without the age effect $\left(\mathrm{IADF}_{a g e}\right)$ and the frequency of intra-annual density fluctuations with the tree-ring width effect removed $\left(\mathrm{IADF}_{t r w}\right)$

\begin{tabular}{llrr}
\hline Descriptors & Difference between partial correlations & Mean & $99 \%$ CI \\
\hline October-February & cor $\left(\mathrm{IADF}_{t r w}-\mathrm{P}\right)-$ cor $\left(\mathrm{IADF}_{a g e}-\mathrm{P}\right)$ & -0.075 & $(-0.122,-0.034)^{*}$ \\
September & cor $\left(\mathrm{IADF}_{t r w}-\mathrm{P}\right)-$ cor $\left(\mathrm{IADF}_{a g e}-\mathrm{P}\right)$ & 0.100 & $(0.072,0.132)^{*}$ \\
\hline
\end{tabular}

For each descriptor, bootstrap mean and confidence interval (CI) were calculated from 10,000 trials

An asterisk $(*)$ indicates that partial correlations were significantly different at $p<0.01$

According to Vieira et al. (2009), young maritime pines form more IADFs than old trees, and similar findings were obtained for Pinus densata Mast. (Bräuning 1999) and Pinus nigra Arn. (Wimmer et al. 2000). Other studies have also shown that IADFs in pine species are more common on wider and younger rings (Rigling et al. 2001, 2002; Copenheaver et al. 2006; Novak et al. 2013b; Campelo et al. 2013). However, we found that in young rings ( $<15$ years) IADF frequency and tree-ring width showed opposite trends, suggesting that variations in intra-ring wood density during the first years should be regulated by cambial age, with tree-growth vigor (tree-ring width) playing a small role on IADF formation. This is supported by the fact that the effect of cambial age on ring density diminished for cambial ages higher than 15 years (Ivković et al. 2013).

According to Novak et al. (2013b), the climatic signal of IADF chronologies could be obscured by the effect of cambial age on IADF formation and they suggested the use of a Weibull function to remove it, before the evaluation of the climatic signal. In our study, the $P$. pinaster IADF frequency estimated by the Weibull function increased with cambial age until the age of 27 and then decreased. Curiously, in $P$. halepensis the peak of IADF frequency was found for the same age (Novak et al. 2013b) suggesting that the effect of cambial age on IADF formation is similar in both species.

The use of the Chapman function is supported by the fact that narrow rings tend to form fewer IADFs (Battipaglia et al. 2010), whereas IADFs are more common on wider rings (Rigling et al. 2001, 2002; Novak et al. 2013b; Campelo et al. 2013). The reason to expect more IADFs in wider rings is the existence of more cells under differentiation during a longer period, which enables the development of IADFs when the triggering factors occur. Longer growing seasons at lower elevations predispose trees to form more IADFs (Rozas et al. 2011; Campelo et al. 2013; Nabais et al. 2014). In our study area, the growing season of $P$. pinaster should span at least 8-10 months from March-April to November-December (Rozas et al. 2011; Campelo et al. 2013). Additionally, a higher number of cells extend the duration of wood formation (Lupi et al. 2010) by delaying the ending of xylem maturation and increasing the time window when environmental factors can be recorded by cells under differentiation. Regarding the triggering factors in the Mediterranean region, it was found that precipitation after the summer drought influenced IADF formation (Battipaglia et al. 2010; De Luis et al. 2011b; Campelo et al. 2013). It was observed that trees of several pine species can resume cambial activity in late summer and early autumn, in response to rainfall events, with a consequent formation of an IADF in latewood (De Luis et al. 2007; Camarero et al. 2010). Recent studies have demonstrated that late summer/early-autumn precipitation can trigger the formation of an IADF, by interrupting the cambial quiescence imposed by summer drought (Camarero et al. 2010; Battipaglia et al. 2010). However, in a xylogenesis study performed in the same species and area, over 2 years (2010 and 2011), a resumption of the cambial activity after the summer was not observed (Vieira et al. 2014). This was probably related to the fact that in those years the low precipitation in September did not allow cambial cell division after the summer drought. We thus hypothesize that if favorable conditions occur during SeptemberOctober, cambial activity could resume, leading to the formation of an IADF at the end of the ring. In fact, this hypothesis is supported by the significant positive correlations between the three types of IADF chronologies and September precipitation. Additionally, the highest correlations found between the standardized IADF chronologies $\left(\mathrm{IADF}_{t r w}\right.$ and $\left.\mathrm{IADF}_{\text {age }}\right)$ and precipitation in September reveal the importance of studying IADFs with the same position within the ring to better identify the triggering factor (Campelo et al. 2007). A temporary drought in spring induces the formation of IADFs in earlywood (Wimmer et al. 2000) and precipitation in September triggers latewood IADFs (Campelo et al. 2007; De Luis et al. 2011b). The selection of the standardization method is crucial to maximize and/or to capture new climate signals in IADF chronologies. For September precipitation, the better climatic signal was attained when the tree-ring width effect was removed from the IADF chronology.

According to the significant partial correlations for standardized IADF chronologies, IADFs in latewood were formed in years with low precipitation before the growing 
season (October-February) and above-average precipitation in September. The combination of these two triggering factors agrees with the general assumption that IADFs are triggered by changing environmental conditions (Wimmer et al. 2000; Battipaglia et al. 2013). Precipitation during the previous winter is important to recharge the soils, with dry winters leading to an earlier start of the drought period and an earlier differentiation of latewood tracheids, making the formation of an IADF more probable when drought is relieved by precipitation during September. This assumption is in agreement with the findings of Vieira et al. (2013) who showed that the first autumn rains can break the quiescent physiological state caused by the reduction of internal water in the tree during the summer drought. Additionally, soil water content regulates lumen size by affecting the turgor pressure of tracheids under differentiation (Abe and Nakai 1999). Indeed, IADFs can be seen as a recording of the tree water status throughout the growing season (Bräuning 1999), which in turn is highly dependent on soil water availability (Battipaglia et al. 2013).

\section{Conclusions}

This is the first study investigating the climatic signal of IADF chronologies using different methods of standardization. Our results show that the relative frequency of IADFs in $P$. pinaster is dependent on age and ring width and that the climatic signal of IADFs time-series depends on the method applied, with the best results obtained when the effect of tree-ring width was removed. Additionally, we have confirmed the value of IADF chronologies of $P$. pinaster, growing under Mediterranean climate with oceanic influence, as a record of intra-annual environmental conditions, namely as a proxy of early-autumn precipitation. Finally, we recommend the use of this new method to standardize time-series of IADFs in other species and sites to amplify their climatic signal.

Author contribution statement FC: writing the paper and analyzing the data. FC and JV: field and laboratory work. JV, GB, MdL, $\mathrm{CN}, \mathrm{HF}$ and PC: reviewing the paper. $\mathrm{CN}$ : coordinating the research project.

Acknowledgments This study was supported by the Fundação para a Ciência e a Tecnologia, Ministério da Educação e Ciência (FCT) cofinanced by Compete, through the project PTDC/AAC-AMB/111675/ 2009. Filipe Campelo was supported by a postdoctoral research grant (SFRH/BPD/47822/2008) from FCT with funds from POPH (Portuguese Operational Human Potential Program) and QREN Portugal (Portuguese National Strategic Reference Framework). Martin de Luis was funded by Spanish Ministry of Education and Science cofunded by FEDER program (CGL2012-31668). This study was conducted in the frame of the COST Action STReESS (FP1106). The authors thank the communicating editor and two anonymous reviewers for helpful comments and suggestions on an earlier version of the manuscript.

Conflict of interest The authors declare no conflict of interest.

\section{References}

Abe H, Nakai T (1999) Effect of the water status within a tree on tracheid morphogenesis in Cryptomeria japonica D Don. Trees 14:124-129. doi:10.1007/PL00009758

Battipaglia G, De Micco V, Brand WA, Linke P, Aronne G, Saurer M, Cherubini $\mathrm{P}(2010)$ Variations of vessel diameter and $\delta^{13} \mathrm{C}$ in false rings of Arbutus unedo L. reflect different environmental conditions. New Phytol 188:1099-1112. doi:10.1111/j.14698137.2010.03443.x

Battipaglia G, DE Micco V, Brand WA, Saurer M, Aronne G, Linke P, Cherubini P (2013) Drought impact on water use efficiency and intra-annual density fluctuations in Erica arborea on Elba (Italy). Plant Cell Environ 37:382-391. doi:10.1111/pce.12160

Bräuning A (1999) Dendroclimatological potential of drought-sensitive tree stands in southern Tibet for the reconstruction of monsoonal activity. IAWA J 20:325-338

Bunn A (2008) A dendrochronology program library in R (dplR). Dendrochronologia 26:115-124. doi:10.1016/j.dendro.2008.01. 002

Camarero JJ, Olano JM, Parras A (2010) Plastic bimodal xylogenesis in conifers from continental Mediterranean climates. New Phytol 185:471-480. doi:10.1111/j.1469-8137.2009.03073.x

Campelo F, Nabais C, Freitas H, Gutiérrez E (2007) Climatic significance of tree-ring width and intra-annual density fluctuations in Pinus pinea from a dry Mediterranean area in Portugal. Ann For Sci 64:229-238. doi:10.1051/forest

Campelo F, García-González I, Nabais C (2012) detrendeR-a graphical user interface to process and visualize tree-ring data using R. Dendrochronologia 30:57-60. doi:10.1016/j.dendro. 2011.01.010

Campelo F, Vieira J, Nabais C (2013) Tree-ring growth and intraannual density fluctuations of Pinus pinaster responses to climate: does size matter? Trees 27:763-772. doi:10.1007/ s00468-012-0831-3

Carrer M, Urbinati C (2004) Age-dependent tree-ring growth responses to climate in Larix decidua and Pinus cembra. Ecology 85:730-740. doi:10.1890/02-0478

Cherubini P, Gartner BL, Tognetti R, Bräker OU, Schoch W, Innes JL (2003) Identification, measurement and interpretation of tree rings in woody species from mediterranean climates. Biol Rev 78:119-148

Copenheaver CA, Pokorski EA, Currie JE, Abrams MD (2006) Causation of false ring formation in Pinus banksiana: a comparison of age, canopy class, climate and growth rate. For Ecol Manage 236:348-355. doi:10.1016/j.foreco.2006.09.020

De Luis M, Gričar J, Čufar K, Raventós J (2007) Seasonal dynamics of wood formation: a comparison between pinning, microcoring and dendrometer measurements. IAWA J 28:389-404

De Luis M, Novak K, Čufar K, Raventós J (2009) Size mediated climate-growth relationships in Pinus halepensis and Pinus pinea. Trees 23:1065-1073. doi:10.1007/s00468-009-0349-5

De Luis M, Novak K, Raventós J, Gričar J, Prislan P, Čufar K (2011a) Cambial activity, wood formation and sapling survival of Pinus halepensis exposed to different irrigation regimes. For Ecol Manage 262:1630-1638. doi:10.1016/j.foreco.2011.07.013

De Luis M, Novak K, Raventós J, Gričar J, Prislan P, Čufar K (2011b) Climate factors promoting intra-annual density fluctuations in 
Aleppo pine (Pinus halepensis) from semiarid sites. Dendrochronologia 29:163-169. doi:10.1016/j.dendro.2011.01.005

De Micco V, Saurer M, Aronne G et al (2007) Variations of wood anatomy and $\delta^{13} \mathrm{C}$ within-tree rings of coastal Pinus pinaster showing intra-annual density fluctuations. IAWA J 28:61-74

De Micco V, Battipaglia G, Brand WA, Linke P, Saurer M, Aronne G, Cherubini P (2012) Discrete versus continuous analysis of anatomical and $\delta^{13} \mathrm{C}$ variability in tree rings with intra-annual density fluctuations. Trees 26:513-524. doi:10.1007/s00468011-0612-4

De Micco V, Battipaglia G, Cherubini P, Aronne G (2014) Comparing methods to analyse anatomical features of tree rings with and without intra-annual density fluctuations (IADFs). Dendrochronologia 32:1-6

Dorado Liñán I, Gutiérrez E, Heinrich I, Andreu-Hayles L, Muntán E, Campelo F, Helle G (2012) Age effects and climate response in trees: a multi-proxy tree-ring test in old-growth life stages. Eur J For Res 131:933-944. doi:10.1007/s10342-011-0566-5

Esper J, Niederer R, Bebi P, Frank D (2008) Climate signal age effects-evidence from young and old trees in the Swiss Engadin. For Ecol Manage 255:3783-3789. doi:10.1016/j. foreco.2008.03.015

Ivković M, Gapare W, Wu H, Espinoza S, Rozenberg P (2013) Influence of cambial age and climate on ring width and wood density in Pinus radiata families. Ann For Sci 70:525-534. doi:10.1007/s13595-013-0290-z

Kunert N, Schwendenmann L, Hölscher D (2010) Seasonal dynamics of tree sap flux and water use in nine species in Panamanian forest plantations. Agric For Meteorol 150:411-419. doi:10. 1016/j.agrformet.2010.01.006

Liu C (1986) Rectifying radii on off-center increment cores. For Sci 32:1058-1061

Lupi C, Morin H, Deslauriers A, Rossi S (2010) Xylem phenology and wood production: resolving the chicken-or-egg dilemma. Plant Cell Environ 33:1721-1730. doi:10.1111/j.1365-3040. 2010.02176.x

Marchand N, Filion L (2012) False rings in the white pine (Pinus strobus) of the Outaouais Hills, Québec (Canada), as indicators of water stress. Can J For Res 42:12-22. doi:10.1139/X11-151

Mencuccini M, Grace J, Fioravanti M (1997) Biomechanical and hydraulic determinants of tree structure in Scots pine: anatomical characteristics. Tree Physiol 17:105-113

Nabais C, Campelo F, Vieira J, Cherubini P (2014) Climatic signals of tree-ring width and intra-annual density fluctuations in Pinus pinaster and Pinus pinea along a latitudinal gradient in Portugal. Forestry 87:598-605. doi:10.1093/forestry/cpu021

Novak K, Luís M, Raventós J, Čufar K (2013a) Climatic signals in tree-ring widths and wood structure of Pinus halepensis in contrasted environmental conditions. Trees 27:927-936. doi:10. 1007/s00468-013-0845-5
Novak K, Sánchez MAS, Čufar K, Raventós J, de Luis M (2013b) Age, climate and intra-annual density fluctuations in Pinus halepensis in Spain. IAWA J 34:459-474. doi:10.1163/ 22941932-00000037

Olivar J, Bogino SM, Spiecker H, Bravo F (2012) Climate impact on growth dynamic and intra-annual density fluctuations in Aleppo pine (Pinus halepensis) trees of different crown classes. Dendrochronologia 30:35-47. doi:10.1016/j.dendro.2011.06.001

Orvis K, Grissino-Mayer H (2002) Standardizing the reporting of abrasive papers used to surface tree-ring samples. Tree-ring Res 58:47-50

Osborn TJ, Briffa KR, Jones PD (1997) Adjusting variance for sample-size in tree-ring chronologies and other regional mean time series. Dendrochronologia 15:89-99

Pereira JS (2002) Pinus pinaster. Pines of silvicultural importance. CABI Publishing, New York, pp 316-328

Rigling A, Waldner PO, Forster T, Bräker OU, Pouttu A (2001) Ecological interpretation of tree-ring width and intraannual density fluctuations in Pinus sylvestris on dry sites in the central Alps and Siberia. Can J For Res 31:18-31. doi:10.1139/cjfr-31$1-18$

Rigling A, Bräker O, Schneiter G, Schweingruber F (2002) Intraannual tree-ring parameters indicating differences in drought stress of Pinus sylvestris forests within the Erico-Pinion in the Valais (Switzerland). Plant Ecol 163:105-122

Rinn F (2003) TSAP-Win: time series analysis and presentation for dendrochronology and related applications. Rinntech, Heidelberg

Rozas V, García-González I, Zas R (2011) Climatic control of intraannual wood density fluctuations of Pinus pinaster in NW Spain. Trees 25:443-453. doi:10.1007/s00468-010-0519-5

Vieira J, Campelo F, Nabais C (2009) Age-dependent responses of tree-ring growth and intra-annual density fluctuations of Pinus pinaster to Mediterranean climate. Trees 23:257-265. doi:10. 1007/s00468-008-0273-0

Vieira J, Campelo F, Nabais C (2010) Intra-annual density fluctuations of Pinus pinaster are a record of climatic changes in the western Mediterranean region. Can J For Res 40:1567-1575. doi:10.1139/X10-096

Vieira J, Rossi S, Campelo F, Freitas H, Nabais C (2013) Seasonal and daily cycles of stem radial variation of Pinus pinaster in a drought-prone environment. Agric For Meteorol 180:173-181. doi:10.1016/j.agrformet.2013.06.009

Vieira J, Rossi S, Campelo F, Freitas H, Nabais C (2014) Xylogenesis of Pinus pinaster under a Mediterranean climate. Ann For Sci 71:71-80. doi:10.1007/s13595-013-0341-5

Wimmer R, Strumia G, Holawe F (2000) Use of false rings in Austrian pine to reconstruct early growing season precipitation. Can J For Res 30:1691-1697. doi:10.1139/cjfr-30-11-1691 